\title{
Effect of Sodium Thiosulphate on the Destiny of Substance engulfed by Histiocytes in the Subcutaneous Connective Tissue affected with the Experimental Glycosuria
}

\author{
$\mathrm{By}$ \\ Toshio Yamane \\ Department of Anatomy, School of Medicine, Yamaguchi University, Ube \\ (Director: Prof. Dr. G. Ji mbo)
}

$\mathrm{L} \mathrm{a} \mathrm{z}$ a r ow (1946) said that the nascentstate inception of the alloxan glycosuria arose from cell destruction caused by the action of alloxan on SH enzyme, perhaps as it should be, in $\beta$ cell of $\mathrm{L}$ a nge rhan s' islet. I think that this opinion is supported by the fact that in the case of the alloxan glycosuria glutathione level in the blood decreases and that by prescribing some $\mathrm{SH}$ chemical compounds such as glutathion, the glycosuria can be prevented from arising.

Hirade (1952) has studied the preventive effect of sodium thiosulphate as a SH chemical compound, O k a moto and others (1950) who had proved that zinc acts upon L a n g e $\mathrm{r}$ h a n s' islet, have observed the excellent effect of sodium thiosulphate, Taka s u $\mathrm{i}$ (1937) had studied the effect of sodium thiosulphate on the antidotal function of the liver of a rabbit by adapting the colorimetry of santonin pigment, and Shimiz a and others (1954) have studied the effect of sodium thiosulphate on the exeprimental glycosuria in the blood.

I have studied the effect of sodium thiosulphate on the destiny of substance gorged by histiocytes in the subcutaneous connective tissue affected with the experimental glycosuria.

\section{Materials and Methods}

As for experimental animals, I prepared thirty mice which were $17-20 \mathrm{~g}$ in weight, assigning five mice for each experimental stage.

As for experimental glycosuria, alloxan was injected into the abdomen of mice at the rate of $0.18 \mathrm{mg}$ per $1 \mathrm{~g}$ of body weight. I 
diluted the sepia, which was taken out of the sepia bursa of a squid, with $0.05 \%$ physiological solution of sodium chloride, and injected $0.05 \mathrm{cc}$ of this solution subcutaneously into the dorsum of the mice which had been injected with alloxan and left for 48 hours. 24 hours later, I injected subcutaneously $1 \mathrm{cc}$ of a $10 \%$ sodium thiosulphate $\left(\mathrm{Na}_{2} \mathrm{~S}_{2} \mathrm{O}_{3}\right)$ into the dorsum of the mice and cut off a small piece of subcutaneous connective tissue out of the dorsum of each mouse at each interval of one, three, six, twenty-four, forty-eight and one hundred hours, and spread out the thin piece on a slide, and stained it according to the ferric hemateinlac method, and fixed it in the formalin solution.

\section{Results}

\section{The macrospcopic observations}

It was observed that the part of the subcutaneous connective tissue of the dorsum, which was injected with sodium thiosulphate, was congested. When I made a specimen of the thin membrane, it spread worse than when normal.

The microscopic observations at various internals of progress. After one hour :

After one hour, namely, 48 hours after injecting alloxan, 24 hours after injecting the sepia and one hour after injecting sodium thiosulphate; it was observed that the subcutaneous connective tissue was slightly grown and moistened and many sepia granules taken into the protoplams of histiocytes seemed to be affected. (Fig. 1)

\section{After three hours :}

It was observed that there was no great change from the state after one hour, but some pigment granules in the protoplasms were slightly grown and moistened and the vacuoles in the protoplasm could be seen in some subcutaneous connective tissues. (Fig. 2)

\section{After six hours :}

It was observed that the vacuolation of some pigment granules was slightly more active and other pigment granules were more grown and moistened than that after three hours, but there was little difference between those after three hours and after six hours, and there was no remarkable change. (Fig. 3)

\section{After twenty-four hours :}

It was observed that the vacuoles in the protoplasms of histiocytes, the growing and moistening sepia, and the vacuolation of the pigment 
granules showed no great change, compared with those after six hours, but they had a tendency to be slightly more active.

\section{After forty-eight hours :}

It was observed that the growing and moistening sepia granules and the vacuoles showed no great change compared with those after 24 hours.

\section{After a hundred hours :}

It was observed that vacuolation in the protoplasms of histiocytes was extremely active; the phagocytosis, the growth and the moisture, and the vacuolation of the sepia granules were obviously changed, compared with those from one hour to 48 hours after; the sepia granules were not scattered in the protoplasms, but were attached to the wall of the vacuoles gathering together. Then the vacuolation in the protoplasms of histiocytes could be seen, but the sepia granules themselves were not greatly grown, moistened or vacuolated.

\section{Discussion}

S e ki and others (1950) said that the excretion of the pigment of histiocytes was due to the vacuoles bursting and excreting their contents. According to Mit s u i (1955), bacteria gorged by histiocytes took new vacuolation and the surface of bacteria burst and excreted the pigment. Y a m a n e (1957) has said that the excretion of the pigment of the histiocyte has relations with the vacuolation of the histiocyte. I made comments of my experiments on the basis of their opinions.

The sepia granules taken into the protoplasm of the histiocyte in the subcutaneous connective tissue, were already grown, moistened and a little changed one hour after sodium thiosulphate was injected. Its variation was a lițtle more active as time went on, but there was no remarkable change. 48-100 hours after injection, it was observed that vacuolation in the protoplasms of histiocytes gradually increased.

This is; the effect of sodium thiosulphate on the destiny of substance gorged by histiocytes in the subcutaneous, connective tissue affected with the experimental glycosuria is very feeble but appears early. Within 48 hours after it was injected its variation was very little. On the excretion of sodium thiosulphate outside the body $\mathrm{Hir}$ a de (1952) said that the excretion was so quick that most of it was excreted 3 hours after $20 \mathrm{cc}$ of $10 \%$ sodium thiosulphate injected into a vein. But on this experiment as I injected them subcutaneously the excretion was a little delayed, but, when I observed the variation in the subcutaneous 
connective tissue and the excretion of sodium thiosulphate outside the body I thought that both should have been corelated, though slightly. It seems to explain the effect of sodium thiosulphate baing more remarkably effective in a short time than expected.

There is room for consideration on the variation of the histiocytes after 100 hours, but it is expected that the excretion of the pigment is worst at that time, taking into consideration of what $0 \mathrm{k} \mathrm{a} \mathrm{moto} \mathrm{(19-}$ 50) has said that the phagocytosis of the sepia of histiocyte became weakest within 2-4 days on the experimental glycosuria. It is not clear whether the function of the histiocytes is revived as time goes on and the vacuolation is found or the sodium thiosulphate affects the excretion of the pigment. And it still has to depend on further studies. The effect of the sodium thiosulphate on the destiny of substance gorged by histiocytes should be said very little.

\section{Conclusion}

1. The effect of the sodium thiosulphate on the destiny of substance gorged by histiocytes in the subcutaneous connective tissue affected with the experimental glycosuria is very little.

2. Within 48 hours after the sodium thiosulphate was injected there is a little variation, but no remarkable change.

3. It is observed there is little vacuolation in the protoplasms of histiocytes and there few growing and moistening sepia granules.

4. There is not any special difference between the effect of the sodium thiosulphate on the absorbing function of the experimental glycosuria and that on the normal histiocytes in subcutaneous connective tissue.

\section{Literature Cited}

1) Bailey C.C., Bailey, O.T. \& Leech, R.S.: 19.14. Alloxan diabetes with diabetic complications, New England. J. Med. $230: 533$.

2) Hirade, J.: 1952. Poisoning and antidote 155. Nankodo press.

3) Laza r ow. A.: 1946. Protective Effect of glutathione and cysteine against alloxan diabetes. Proc. Soc. Exp. Biol. \& Med. 61, 441.

4) M i i, Y. 1955. Veränderungen der Färbbarkeit mit Viktoriablau der in den Bindegewebs Zellen aufgenommenen Tuberkelbazillen. Arch. hist. jap. 8:438.

5) $\mathrm{O}$ k a m ot o, K. 1950. On the pathogenesis of glycosuria. Igakunoayumi. 10:1

6) Shimizu, Y., Shimizu, T., Wada, M., Nakasawa, S. 1954. On the effect of hypo upon detoxication function of rabbit liver by means of so called specific gravity estimation of santonin pigment. Progressive study of SH group. Igakushoin press. 1954. 
7) Seki, M. \& I ta oka, K. 1950. On the changes of the fibrohistiocytic system following the inhalation of sulphur gas. Arch. hist. jap. $1: 210$.

8) Takasugi, T. Mi y a moto, E. 1937. On the comperative effect of hypo, taurin and cystine upon alloxan and dehydroascorbic acid glycosuria. J. J.S. I. M. $25: 944$

9) Y a m a n e, T. 1957. On the effect of periston " $N$ " on the excretion pigment histiocytes in the subcutaneous connective tissue affected with the experimental glycosuria. Arch. hist. jap. $12: 329-344$.

\section{Explanation of Figures}

Fig. 1. Cells of connective tissue one hour after injecting sodium thiosulphate in an experimental glycosuria. $\times 600$

Fig. 2. Cells of connective tissue 3 hours after injecting sodium thiosulphate in an experimental glycosuria. $\times 600$

Fig. 3. Cells of connective tissue 6 hours after injecting sodium thiosulphate in an experimental glycosuria. $\times 600$

Fig. 4. Cells of connective tissue 24 hours after injecting sodium thiosulphate in an experimental glycosuria. $\times 600$

Fig. 5. Cells of connective tissue 48 hours after injecting sodium thiosulphate in an experimental glycosuria, $\times 600$

Fig. 6. Cells of connective tissue 100 hours after injecting sodium thiosulphate in an experimental glycosuria. $\times 600$ 
Plate

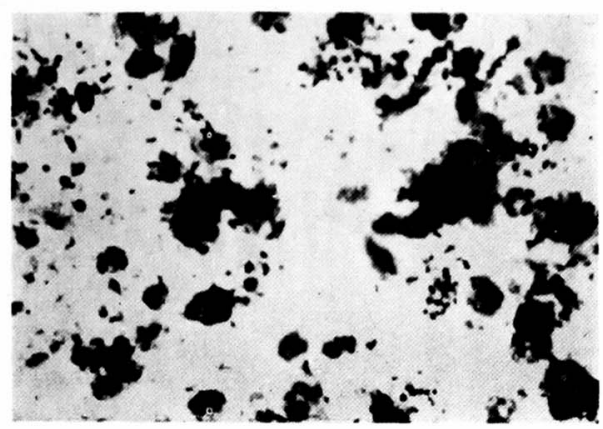

Fig. 1.

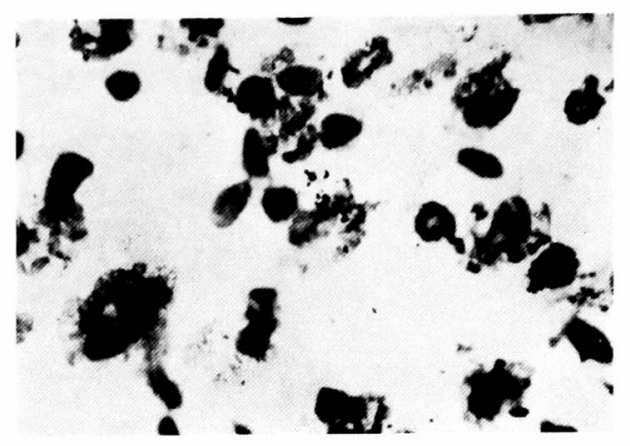

Fig. 2.

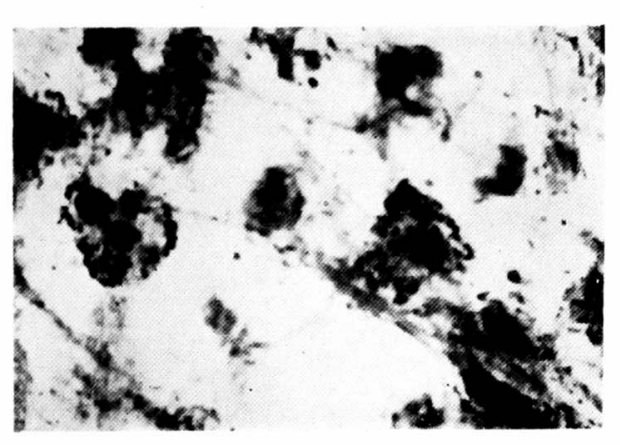

Fig. 3.

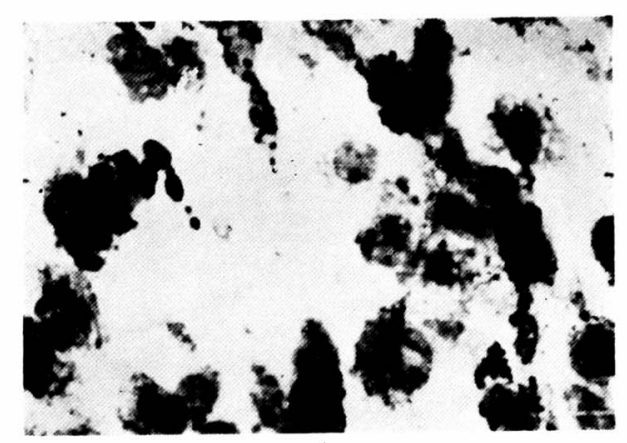

Fig. 4.

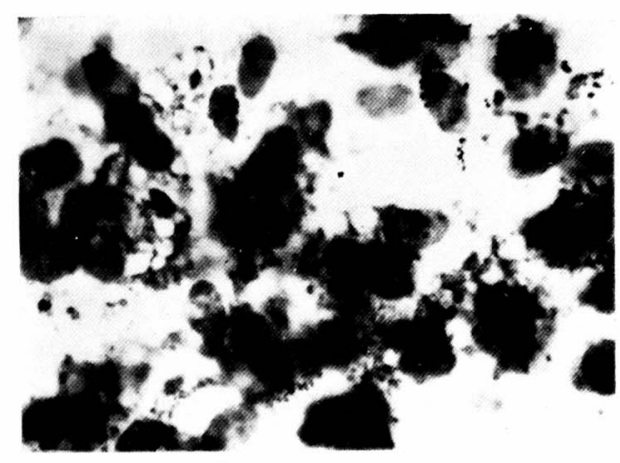

Fig. 5.

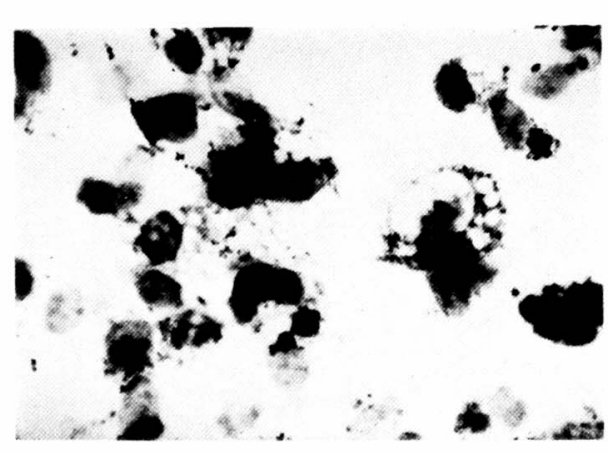

Fig. 6. 